\title{
Allochthonous Organic Matter Supports Benthic but Not Pelagic Food Webs in Shallow Coastal Ecosystems
}

\author{
Pia Bartels, ${ }^{1 *}$ Jenny Ask, ${ }^{1}$ Agneta Andersson, ${ }^{1,2}$ Jan Karlsson, ${ }^{1,3}$ and \\ Reiner Giesler ${ }^{1,3}$
}

\begin{abstract}
${ }^{1}$ Department of Ecology and Environmental Science, Umea University, 90187 Umeå, Sweden; ${ }^{2}$ Umea Marine Sciences Centre, Norrbyn, Sweden; ${ }^{3}$ Climate Impacts Research Centre (CIRC), Department of Ecology and Environmental Science, Umea University, Abisko, Sweden
\end{abstract}

\begin{abstract}
Rivers transport large amounts of allochthonous organic matter $(\mathrm{OM})$ to the ocean every year, but there are still fundamental gaps in how allochthonous OM is processed in the marine environment. Here, we estimated the relative contribution of allochthonous OM (allochthony) to the biomass of benthic and pelagic consumers in a shallow coastal ecosystem in the northern Baltic Sea. We used deuterium as a tracer of allochthony and assessed both temporal variation (monthly from May to August) and spatial variation (within and outside river plume). We found variability in allochthony in space and time and across species, with overall higher values for zoobenthos $(26.2 \pm 20.9 \%)$ than for zooplankton $(0.8 \pm 0.3 \%)$. Zooplankton allochthony was highest in May and very low during the other months, likely as a result of high inputs of allochthonous OM during the spring flood that fueled the pelagic food chain for a short
\end{abstract}

Received 5 June 2017; accepted 30 January 2018;

published online 23 February 2018

Electronic supplementary material: The online version of this article (https://doi.org/10.1007/s10021-018-0233-5) contains supplementary material, which is available to authorized users.

Authors' contribution $\mathrm{PB}$ and JA designed the study with contribution from AA, JK, and RG. PB and JA performed the research. PB analyzed the data and wrote the first draft of the manuscript. All authors contributed substantially to the final version of the manuscript.

*Corresponding author; e-mail: pia.bartels.pb@gmail.com period. In contrast, zoobenthos allochthony was only lower in June and remained high during the other months. Allochthony of zoobenthos was generally higher close to the river mouth than outside of the river plume, whereas it did not vary spatially for zooplankton. Last, zoobenthos allochthony was higher in deeper than in shallower areas, indicating that allochthonous OM might be more important when autochthonous resources are limited. Our results suggest that climate change predictions of increasing inputs of allochthonous OM to coastal ecosystems may affect basal energy sources supporting coastal food webs.

Key words: climate change; terrestrial organic carbon; stable isotope analysis; autochthonous production; benthic-pelagic coupling; food webs; Bothnian Sea. 


\section{INTRODUCTION}

Climate change, alterations in land use, and reversed acidification lead to increasing inputs of terrestrial organic matter $(\mathrm{OM})$ to inland waters worldwide (Monteith and others 2007; Clark and others 2009). Large amounts of this allochthonous OM (that is, OM of terrestrial origin) are processed in surface waters (Cole and others 2007; Tranvik and others 2009), but the remaining fraction eventually drains into the sea. Organic carbon is the major constituent of allochthonous OM, and rivers transport about $0.45 \mathrm{Pg}$ of allochthonous organic carbon to the ocean every year (Cole and others 2007). However, little of the allochthonous OM appears to persist in the ocean, both in the water column and in sediments (Hedges and others 1997; Opsahl and Benner 1997; Bianchi and Allison 2009). For decades, studies have aimed to understand the fate of allochthonous OM in marine ecosystems (Hedges and others 1997). However, to what extent allochthonous OM can support various compartments of marine food webs remains largely unknown (Hedges and others 1997; Dagg and others 2004).

Estuaries are transition zones between freshwater and marine environments. These ecosystems act as reactors that modify quantities and characteristics of allochthonous OM through several biogeochemical, physical, and biological processes (for example, Dagg and others 2004). During estuarine transit, some fraction of dissolved and particulate allochthonous OM can be incorporated into estuarine and coastal food webs. Ample studies show that allochthonous organic carbon can support pelagic bacterial production (Albright 1983; ChinLeo and Benner 1992; McCallister and others 2004). The bacterial biomass supported by allochthonous carbon might further "subsidize" zooplankton and fish through incorporation via the microbial food web (Jansson and others 2007), although some studies suggest that much of the production does not reach higher trophic levels (for example, Cole and others 2006). Particulate allochthonous $\mathrm{OM}$ and aggregates that form from dissolved allochthonous OM (Sholkovitz 1976) sink to the bottom at the freshwater-marine interface and may be utilized by benthic communities (Fockedey and Mees 1999). Higher trophic levels such as fish often rely to a large extent on benthic resources (Vander Zanden and Vadeboncoeur 2002; Hampton and others 2011), suggesting the utilization of zoobenthos as an important entry route for allochthonous $\mathrm{OM}$ into estuarine and coastal food webs.

Inputs of allochthonous OM to aquatic ecosystems often vary over time and space (Minor and others 2006; Yamashita and others 2011). Several studies demonstrated that the utilization of allochthonous $\mathrm{OM}$ by benthic consumers declined with distance from the freshwater source in coastal ecosystems (Peterson and others 1985; Antonio and others 2010; Careddu and others 2015). Furthermore, utilization of allochthonous OM might increase with increasing depth (Premke and others 2010). Such spatial variation in the utilization of allochthonous OM may be caused by shifts in primary carbon sources along environmental gradients, for example by higher availability of allochthonous OM closer to the river mouth than further offshore and by reduced benthic primary production due to decreased light availability with increasing depth (Ask and others 2016). Similarly, the utilization of allochthonous OM by consumers may vary over time. For instance, Figueroa and others (2016) demonstrated that bacterioplankton production in a subarctic estuary peaked during the spring flood, and Montero and others (2011) suggested that allochthonous OM played an important role for bacterioplankton in winter when autochthonous production was low.

Previous studies evaluating the effect of allochthonous $\mathrm{OM}$ on estuarine consumers have investigated benthic and pelagic habitats separately (but see for example, Dunton and others 2006). There is a lack of studies investigating how allochthonous OM affects both habitats simultaneously and whether patterns in allochthonous OM utilization of benthic and pelagic consumers vary similarly in time and space. This is important as habitats are coupled through several pathways (Schindler and Scheuerell 2002) and fish in particular often integrate benthic and pelagic habitats (Vander Zanden and Vadeboncoeur 2002). For instance, increasing inputs of allochthonous OM predicted by climate change scenarios have been suggested to decrease production of fish as phytoplankton production decreases (Andersson and others 2015), although the utilization of zoobenthos might "compensate" for potential losses in pelagic production. Here, we investigate the utilization of allochthonous OM of benthic and pelagic consumers in an estuary in the northern Baltic Sea. We hypothesize that allochthonous OM would 
(1) contribute to a larger extent to zoobenthos than to zooplankton. Moreover, we hypothesize that allochthonous OM utilization of both zoobenthos and zooplankton would (2) vary temporally, showing the largest contribution in the beginning of the growing season, and (3) vary spatially, showing increasing contribution with decreasing distance from the river mouth and with increasing depth. Last, we hypothesize that (4) the contribution of allochthonous OM to fish would vary among species with high contribution to species that spend large periods of time in the estuary and low contribution to species that spend large periods of time offshore.

\section{MethodS}

\section{Study Site}

The Baltic Sea is a semi-enclosed brackish sea with minimal tidal influence. Our study site was located in the Gulf of Bothnia, the northern part of the Baltic Sea, at the margin between the Bothnian Bay in the north and the Bothnian Sea in the south (Figure 1A). In the Bothnian Gulf, as much as 70$92 \%$ of the dissolved OM pool might be derived from terrestrial sources (Alling and others 2008). Faunal diversity is generally low in the entire Baltic Sea, and, especially in the north, a major part of the biomass consists of only a few species. During the last decades, the Baltic Sea was subject to several invasions (Olenin and Leppäkoski 1999) with some invaders, such as Marenzellaria viridis, successfully establishing in the northern parts. Our study area, the Öre estuary, is small and shallow $\left(50 \mathrm{~km}^{2}\right.$ area; $35 \mathrm{~m}$ maximum, and $15 \mathrm{~m}$ mean depth, respectively) and relatively open toward offshore areas with no marked sill. The Öre River catchment has an area of $2940 \mathrm{~km}^{2}$, which mainly consists of boreal coniferous forest and mires. Spring floods typically occur in April and May and comprise 50$70 \%$ of the total yearly runoff (Brydsten and Jansson 1989), whereas summers are usually characterized by low runoff. The studied estuary is representative for coastal areas in the northern Baltic Sea. This includes for instance similar seasonal variation of phosphorus and nitrogen concentrations, salinity, and Secchi depth (for example, Figueroa and others 2016).

\section{Sampling}

Four stations were sampled monthly from May to August 2015; three along the estuary (hereafter S1, S2, and S3) and one reference station (hereafter S4) north of the river without significant freshwa- ter input (Figure 1B). At S1, S3, and S4, we sampled at approximately 1,3 , and $10 \mathrm{~m}$ depth. S2 was located at a very exposed, rocky, and steep shore, and therefore we sampled no shallow locations. No samples were taken at S2 in July. At the 10-m locations, we obtained depth profiles of salinity and colored dissolved organic matter (CDOM), using a SEAGUARD CTD (Aanderaa) at each sampling occasion. The CDOM recorded by the SEAGUARD is a qualitative measurement of the ability of dissolved carbon to fluorescence using an excitation wavelength of $350 \mathrm{~nm}$ and an emission wavelength of $450 \mathrm{~nm}$ and is used here as a proxy for humic substances. In addition, total nitrogen (TN), total phosphorus (TP), dissolved and total organic carbon (DOC and TOC, respectively), and chlorophyll $a$ were taken at $0.5 \mathrm{~m}$ depth and at approximately $1 \mathrm{~m}$ above the sediment at each sampling occasion using a Ruttner sampler. Nutrient samples were kept cold and dark and were analyzed within $4 \mathrm{~h}$ after sampling using a Bran 8 Luebbe TRAACS 800 auto-analyzer following Grasshof and others (1983). No nutrient samples were taken in July. Samples for DOC were filtered $(0.2 \mu \mathrm{m})$. TOC and DOC samples were acidified with $1.2 \mathrm{M} \mathrm{HCl}$ and stored in the fridge until further analyses. TOC and DOC were analyzed using a Shimadzu TOC-5000. Chlorophyll $a$ samples were filtered on GF/F filters and frozen until further analyses. Chlorophyll $a$ was extracted in $95 \%$ ethanol and measured using a PerkinElmer LS30 fluorometer $(433 \mathrm{~nm}$ excitation wavelength and $674 \mathrm{~nm}$ emission wavelength). Data for water discharge (Figure 1C) were taken from the Öre River monitoring station (63.7017N; 19.6037E), available at http:// vattenweb.smhi.se/station/, which is some $30 \mathrm{~km}$ upstream.

We collected periphyton from rocks at the shore in May, June, and August (Table S1) to derive an autochthonous end-member for $\delta^{2} \mathrm{H}_{\text {auto }}$ (Karlsson and others 2012). Zooplankton were sampled monthly by trawling a zooplankton net $(100 \mu \mathrm{m}, \varnothing$ $50 \mathrm{~cm}$ ) at approximately $1 \mathrm{~m}$ below the surface behind the boat (at 10-m locations). Three trawls were made at each station. Zooplankton were sorted into cladocerans (Bosmina sp., Evadne sp., Daphnia sp.) and into copepods of two size fractions (<and $>200 \mu \mathrm{m}$, respectively). The size fraction $<200 \mu \mathrm{m}$ consisted mostly of nauplii and to some extent rotifers, whereas the size fraction $>200 \mu \mathrm{m}$ was dominated by calanoid copepods. Additionally, one quantitative zooplankton sample was taken at $10 \mathrm{~m}$ at S1, S3, and S4 by vertically hauling a plankton net $(30 \mu \mathrm{m}, \varnothing 25 \mathrm{~cm})$ from $1 \mathrm{~m}$ above the sediment to the surface. 

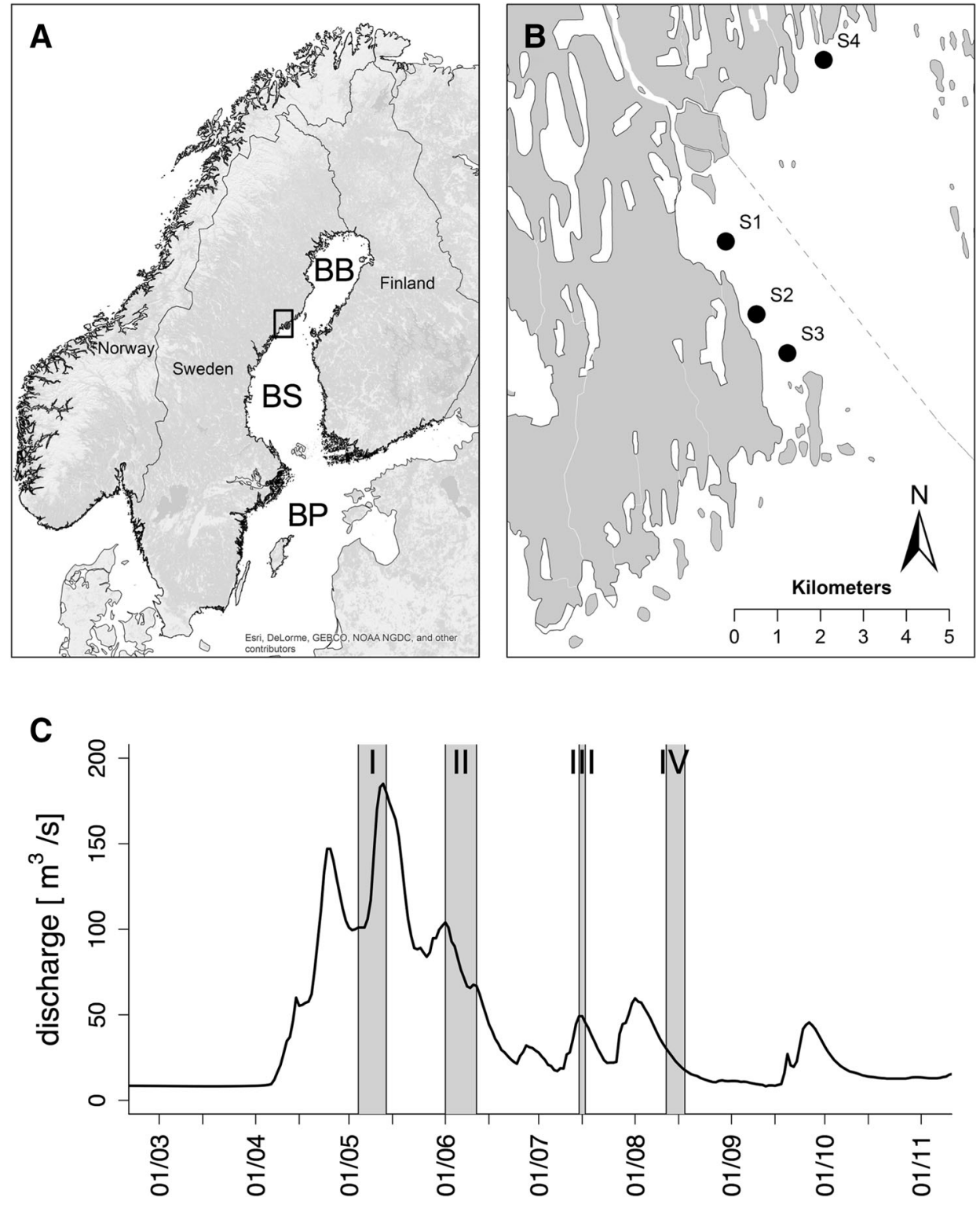

Figure 1. Map over sampling site $(\mathbf{A})$, detailed map over 10-m sampling stations $(\mathbf{B})$, and water discharge $(\mathbf{C})$ at the Öre River monitoring station between March and November 2015. Shaded areas depict sampling periods in (I) May, (II) June, (III) July, and (IV) August. Data are available at http://vattenweb.smhi.se/station/. BB Bothnian Bay, BS Bothnian Sea, BP Baltic Proper.

Zoobenthos were collected monthly at 1,3 , and $10 \mathrm{~m}$ at S1, S3, and S4 and at $10 \mathrm{~m}$ at S2 with an Ekman grab. At each depth, three grabs were taken. Zoobenthos were stored in GF/F-filtered seawater for gut evacuations for $12-24 \mathrm{~h}$ and were then separated and washed with MilliQ water. For chironomids, Marenzellaria, Macoma, and oligochaets, 3-15 individuals were pooled before grinding, whereas Saduria and Corophium were used individually as biomass of these species was generally low. Monoporeia was only common in $\mathrm{Au}-$ gust; thus, we used single specimen in May, June, and July, but pooled 3-5 individuals in August. Gastropods and bivalves were removed from their shells. We sampled European perch, Perca fluvialitis ( $n=20$, total length (TL): $162.9 \pm 40.0 \mathrm{~mm})$, 9spined sticklebacks, Pungitius pungitius ( $n=27$, TL: $48.7 \pm 3.5 \mathrm{~mm})$, and 3-spined sticklebacks, Gasterosteus aculeatus $(n=30$, TL: $63.4 \pm 5.0 \mathrm{~mm})$, as they are common in coastal areas of the Baltic Sea. The latter spends large parts of the year in the pelagic but migrates to coastal areas in spring to spawn (Borg 1985). Sticklebacks were sampled at S1, S3, and S4 with a beach seine in June, and by 
hand-netting in August. Perch were sampled in the Öre estuary in August as part of the monitoring survey of the Umeå Marine Sciences Centre with standardized multi-mesh gillnets. For adult fish, dorsal muscle tissue was used for stable isotope analyses. Young-of-the-year (YOY) sticklebacks $(n=8)$ were used whole. Water for $\delta^{2} \mathrm{H}$ analysis was taken at every sampling occasion (Table S1), filtered $(0.2 \mu \mathrm{m})$, and stored in airtight glass bottles without air bubbles until further analyses. All solid samples for isotopic analyses were freeze-dried, homogenized if necessary, and stored frozen until further analyses.

\section{Stable Isotope Analyses}

Stable isotope analyses were carried out at the UC Davis Stable Isotope Facility of California at Davis (CA) for $\delta^{15} \mathrm{~N}$ by continuous-flow isotope ratio mass spectrometry (PDZ Europa 20-20; Sercon, Cheshire, UK). Analyses of the $\delta^{2} \mathrm{H}$ of non-exchangeable $\mathrm{H}$ were carried out at the Colorado Plateau Stable Isotope Laboratory in Flagstaff (AZ). Samples and standards were equilibrated with local water vapor to correct for exchangeable $\mathrm{H}$. Analysis of solid samples was carried out by pyrolysis and measurement of isotopic composition of $\mathrm{H}_{2}$ gas using isotope ratio mass spectrometry. The $\delta^{2} \mathrm{H}$ of water samples was analyzed by headspace equilibration with $\mathrm{H}_{2}$ gas and a platinum catalyst using isotope ratio mass spectrometry. The data are expressed in per mil $(\%)$ notion relative to Vienna Standard Mean Ocean Water (VSMOW) for $\delta^{2} \mathrm{H}$ and atmospheric nitrogen for $\delta^{15} \mathrm{~N}$. Some samples were analyzed in triplicates, and the analytic error was 3.8 and $0.2 \%$ for $\delta^{2} \mathrm{H}$ and $\delta^{15} \mathrm{~N}$, respectively.

\section{Calculations of Allochthony}

To calculate the relative contribution of allochthonous OM to consumer biomass (that is, allochthony), we applied a 2-isotope $\left(\delta^{2} \mathrm{H}\right.$ and $\left.\delta^{15} \mathrm{~N}\right)$, 2 -source Bayesian mixing model with SIAR (version 4.2; Parnell and Jackson 2013) for R (R Core Team 2016). Trophic fractionation for $\delta^{15} \mathrm{~N}$ was set to $2.2 \pm 1.8 \%$ for primary consumers and $1.4 \pm 0.9 \%$ per trophic transfer for all predators (McCutchan and others 2003). Applying a higher fractionation factor $(3.4 \%$; Post 2002) did not change allochthony in our study (not shown). We assigned the number of trophic transfers to 1 for zooplankton and all benthic invertebrates except Saduria, to 2 for sticklebacks and Saduria, and to 3 for perch. Trophic fractionation for $\delta^{2} \mathrm{H}$ was set to 0 (Solomon and others 2009). Consumer $\delta^{2} \mathrm{H}$

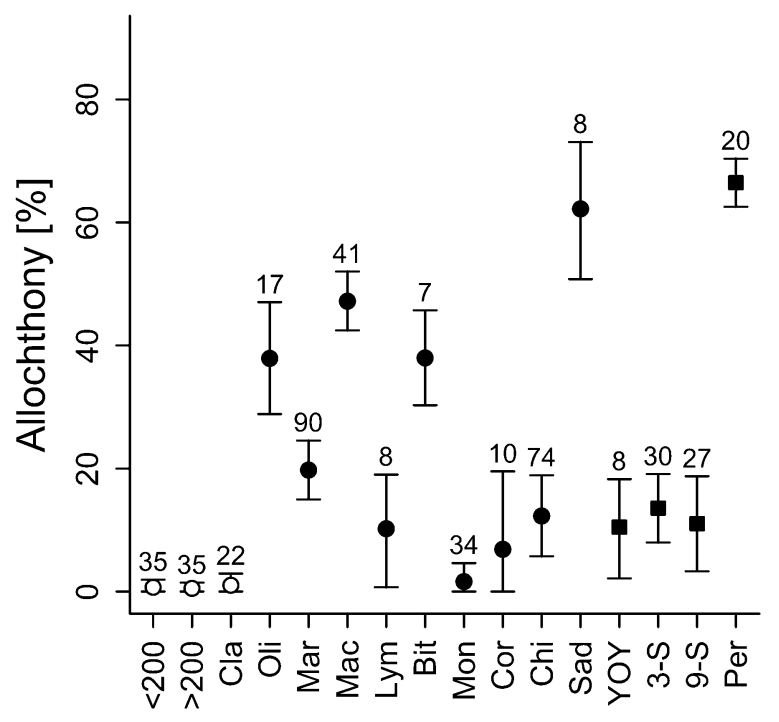

Figure 2. Allochthony in zooplankton (open circle), zoobenthos (filled circles), and fish (filled squares). Shown are mean values ( $\pm 95 \%$ credibility internals) across all stations and sampling dates. Numbers denote sample size. $<200=$ Zooplankton $<200 \mu \mathrm{m},>200=$ Zooplankton $>200 \mu \mathrm{m}$. Clad Cladocera, Oli Oligochaets, Mar Marenzellaria, Mac Macoma, Lym Lymnaea, Bit Bithynia, Mon Monoporeia, Cor Corophium, Chi Chironomids, Sad Saduria, YOY 3-spined YOY sticklebacks, 3-S 3-spined sticklebacks, 9-S 9-spined sticklebacks, Per perch.

$\left(\delta^{2} \mathrm{H}_{\text {cons }}\right)$ values were corrected for dietary water prior to input into the mixing model as

$$
\delta^{2} \mathrm{H}_{\text {corr }}=\left(\delta^{2} \mathrm{H}_{\text {cons }}-\omega \times \delta^{2} \mathrm{H}_{\text {wat }}\right) /(1-\omega)
$$

The $\omega$ is the contribution of dietary water to consumer ${ }^{2} \mathrm{H}$ (0.22; Wilkinson and others 2015). $\delta^{2} \mathrm{H}_{\text {wat }}$ ranged between -71.1 and $-102.6 \%$ and varied over space and time (station: $F_{3,8}=5.33$, $P=0.026$; date: $\left.F_{3,8}=9.98, P=0.004\right)$. Therefore, we used specific measurements for each sampling station and date (Table S1). As the allochthonous end-member in the mixing model, we used published values of leaf litter OM $\left(\delta^{2} \mathrm{H}_{\text {allo }}=-153.6 \pm\right.$ $8.2 \%, \delta^{15} \mathrm{~N}_{\text {allo }}=0.99 \pm 2.11 \%$; Jonsson and Stenroth 2016). As the autochthonous end-member, we used our own data $\left(\delta^{2} \mathrm{H}_{\text {auto }}=-229.5 \pm 9.2 \%\right.$, $\delta^{15} \mathrm{~N}_{\text {auto }}=1.8 \pm 1.0 \%$. . Our estimates of $\delta^{2} \mathrm{H}_{\text {auto }}$ were similar to previous estimates of algal $\delta^{2} \mathrm{H}$ signatures in freshwater (Doucett and others 2007; Karlsson and others 2012).

We ran three different mixing models. In model 1, we grouped our data based on taxon, that is, independent of sampling date or location (Figure 2). In model 2, we grouped our data based on taxonomic group (benthos and zooplankton, respectively), sampling date, and sampling station 

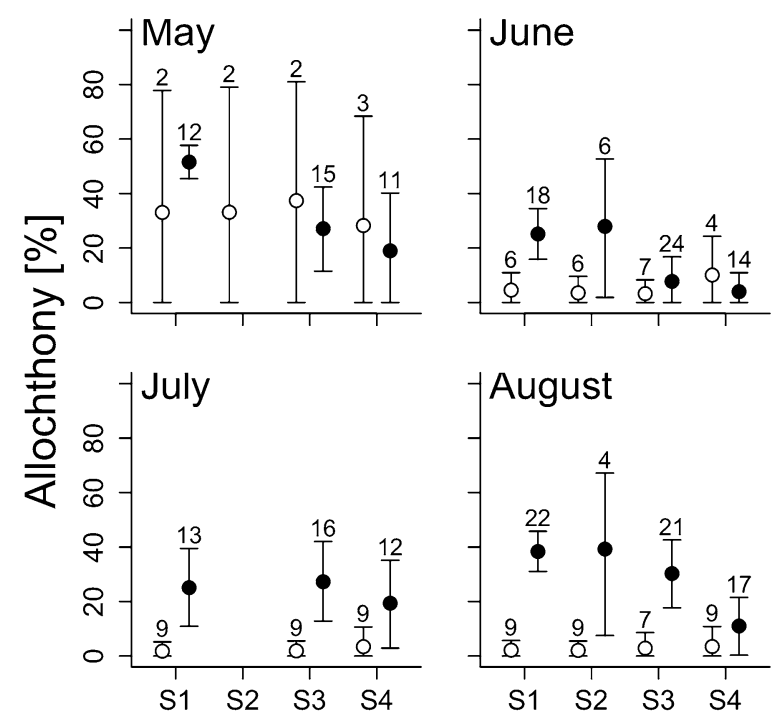

Figure 3. Allochthony (mean $\pm 95 \%$ credibility internals) in zooplankton (open symbols) and zoobenthos (filled symbols) across the four sampling stations in May, June, July, and August. Zoobenthos includes only Marenzellaria, Macoma, and chironomids. Numbers denote sample size.

(Figure 3; Table S3). We only included the three most common taxa, namely Marenzellaria, Macoma, and chironomids in this analysis. Data from longterm monitoring close to our sampling stations showed that Macoma and Marenzellaria account for more than $85 \%$ of the total biomass at all stations (Table S2). We additionally included chironomids as they were common at the shallower stations. In model 3, we grouped only the most common benthic taxa based on sampling date, sampling station, and sampling depth (Figure 4; Table S4). Station 2 was excluded from the last model as sampling was only performed at $10 \mathrm{~m}$ depth at this station. For most consumers, the resulting probability distributions for allochthonous and autochthonous contributions were precise and not skewed; however, for amphipods and zooplankton, the distributions were skewed toward the autochthonous end-member, likely due to high uncertainty in $\omega$. Thus, although the contribution of allochthonous resources to these groups was very low, the absolute values should be interpreted with caution.

\section{Statistical Analyses}

Statistical analyses of water chemistry were performed in R 3.2.4 (R Core Team 2016).

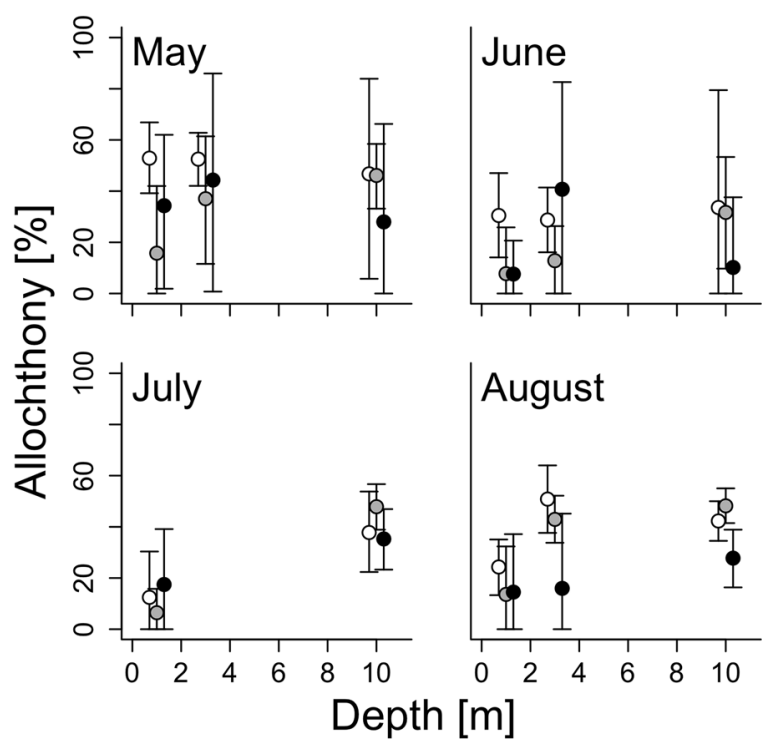

Figure 4. Allochthony (mean $\pm 95 \%$ credibility internals) across depth for S1 (white), S3 (gray), and S4 (black) in May, June, July, and August.

\section{RESUltS}

\section{Seasonal and Spatial Variation in Water Chemistry}

Our first sampling coincided with the peak of the spring flood, where water discharge was on average 4.5 times higher than during late summer (Figure 1C). Salinity varied between 0.04 and 6.00 PSU at the sampling stations (Tables 1, S5). Freshwater inflow was highest at S1 in May but was also high in July and August. During these occasions, a freshwater layer of 1-3 $\mathrm{m}$ depth was observed above the brackish water (Figure S1). S2 showed a similar stratification pattern in May. In June, little stratification was observed below $4 \mathrm{~m}$ depth, whereas in August, stratification was observed in deeper layers (>6 m; Figure S1). Salinity was strongly correlated with CDOM $(r=-0.80$, $P<0.001$; not shown). CDOM concentrations were highest at S1 (Tables 1, S5) and generally followed the patterns of salinity (Figure S2).

Overall, nutrient concentrations did not differ between stations in surface or deep-water samples (Table 2). For surface samples, TOC did not differ between stations, but sampling stations differed in CDOM and marginally in DOC (Table 2). This was mainly due to higher concentrations at S1 than at S4. Carbon concentrations (TOC, CDOM, and DOC) did not differ in deep-water samples. 


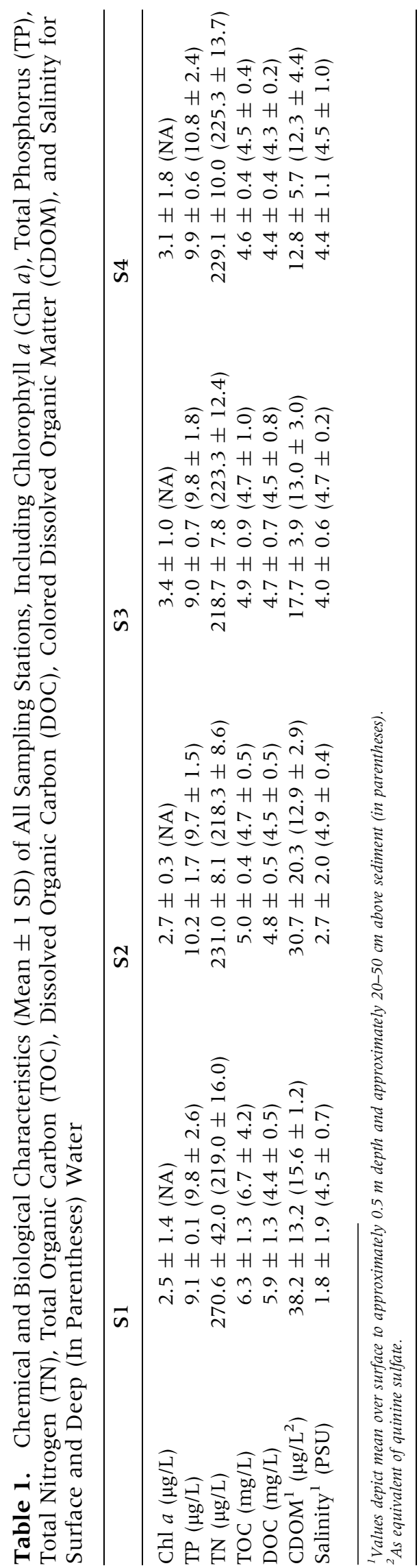

\section{Consumer Allochthony}

The most prevalent benthic animals were the invasive polychaete Marenzellaria viridis, the clam $\mathrm{Ma}$ coma balthica, and chironomids (Tables S6). Other common animals were the amphipods Corophium volutator and Monoporeia affinis, the predatory isopod Saduria entomon, oligochaets, and the gastropods Bithynia sp. and Lymnaea sp. Overall, allochthony was higher for zoobenthos $(26.2 \pm 20.9 \%)$ than for zooplankton $(0.8 \pm 0.3 \%$; Figure 2$)$. Among benthic animals, the contribution of allochthonous OM was lowest to Monoporeia and Corophium, whereas Saduria showed the highest allochthony (Figure 2). Allochthony in sticklebacks was much lower $(11.7 \pm 1.6 \%)$ than for perch (66.5\%; Figure 2$)$.

Zooplankton biomass was dominated by calanoid copepods, and cladocerans became more abundant only in August (Table S7). Zooplankton allochthony was generally higher at all stations in May $(28.3-33.1 \%)$ than in the other sampling months $(1.8-10.1 \%)$ but was similar among stations within each sampling date (Figure 3; Table S3).

For the most common benthic taxa (Marenzellaria, Macoma, and chironomids), allochthony was highly variable among sampling dates, sampling stations, and depths (Figure 3, 4; Table S3, S4). Allochthony was highest at S1 in May $(51.6 \%)$ and also high at S1 and S2 in August (38.4 and 39.3\%, respectively) and lowest in June at S3 and S4 (7.8 and $4.0 \%$, respectively; Table S3). Generally, the contribution of allochthonous OM was lower at S4 than at S1, although the mean difference was small in July (Figure 3; Table S3). Last, allochthony was higher at $10 \mathrm{~m}$ depth than at $1 \mathrm{~m}$ depth in July and August, whereas there was no apparent difference in allochthony among depths at the beginning of the sampling (Figure 4; Table S4).

\section{Discussion}

Carbon loadings from rivers to marine environments in the Northern Hemisphere are expected to increase in the future (Freeman and others 2001; Tranvik and Jansson 2002) and may have pronounced impacts on coastal ecosystems. Here, we demonstrated that the contribution of allochthonous OM differed largely between benthic and pelagic consumers with zoobenthos generally relying to a larger extent on allochthonous OM than zooplankton. We further illustrated that the contribution of allochthonous OM varied spatially and temporarily. Our study highlights that allochthonous OM is incorporated into coastal food 
Table 2. Statistical Results for Comparison of Water Chemistry Between Stations for Surface (0.5 m) and Deep ( $1 \mathrm{~m}$ Above Sediment) Water Samples

\begin{tabular}{|c|c|c|c|c|c|c|}
\hline & \multirow[b]{2}{*}{$n$} & \multirow[b]{2}{*}{$d f$} & \multicolumn{2}{|l|}{ Surface } & \multicolumn{2}{|l|}{ Deep } \\
\hline & & & $F$ value & $P$ value & $F$ value & $P$ value \\
\hline Chl $a$ & 15 & 3 & 0.56 & 0.65 & NA & NA \\
\hline $\mathrm{TP}$ & 12 & 3 & 1.09 & 0.41 & 0.16 & 0.92 \\
\hline $\mathrm{TN}$ & 12 & 3 & 3.54 & 0.07 & 0.20 & 0.89 \\
\hline TOC & 14 & 3 & 2.70 & 0.10 & 0.71 & 0.57 \\
\hline DOC & 15 & 3 & 2.74 & 0.09 & 0.11 & 0.95 \\
\hline CDOM & 15 & 3 & 3.92 & 0.040 & 0.89 & 0.48 \\
\hline Salinity & 15 & 3 & 2.73 & 0.09 & 0.23 & 0.85 \\
\hline
\end{tabular}

webs; however, its contribution to consumer biomass differs between habitats and consumers.

In coastal and estuarine ecosystems, the major available resources to consumers comprise of phytoplankton, benthic microalgae, and detritus that may originate from terrestrial, freshwater, or marine sources (Bode and others 2011). We demonstrated that allochthonous OM supported zoobenthos, whereas its contribution to zooplankton was generally low. This was in line with our first hypothesis and might be explained by differences in mechanisms of how allochthonous OM is incorporated into benthic and pelagic food webs. The major pathway of allochthonous OM entering pelagic food webs is likely through the microbial food web (Jansson and others 2007). Multiple studies have demonstrated that allochthonous OM can fuel pelagic heterotrophic bacteria (Albright 1983; Chin-Leo and Benner 1992; McCallister and others 2004). The transfer from heterotrophic bacteria to metazoans requires additional trophic levels before it reaches zooplankton and results in large carbon losses through respiration (Jansson and others 2007). In contrast, although allochthonous OM also supports benthic heterotrophic bacteria (Ask and others 2009), the incorporation of allochthonous OM into benthic food webs is likely more direct via use of particles and aggregates of allochthonous OM that form and settle at the sediment surface in the estuary (Sholkovitz 1976). Studies from the southern Baltic Sea showed that as much as $40-70 \%$ of the bulk sediment is of terrestrial origin (for example, Szczepanska and others 2012). The allochthonous OM in the sediment can provide a substrate for benthic animals (Fockedey and Mees 1999) and can support benthic metabolism (Hopkinson and Vallino 1995). Thus, high availability of allochthonous OM in sediments and direct consumption likely explain higher al- lochthony in zoobenthos compared to zooplankton.

Other reasons for low allochthony in zooplankton might be that heterotrophic bacterial production was not stimulated by allochthonous OM and/ or that phytoplankton production was simply sufficient to support zooplankton growth. Although several studies demonstrated that bacterial production can be stimulated by allochthonous OM (Albright 1983; Chin-Leo and Benner 1992; McCallister and others 2004), it has also been argued that much of the $\mathrm{OM}$ is a relatively poor substrate for bacterial growth (Meybeck 1982; Ittekkot 1988). For our study system, Wikner and others (1999) demonstrated that bioavailability of dissolved organic carbon in the estuary ranged between undetectable values and $20 \%$ over an approximately two-year period with higher bioavailability during spring floods than intermediate periods. However, bacterial growth efficiency was relatively low, suggesting that much of the bioavailable carbon was used for respiration (Wikner and others 1999). Autochthonous OM provides a more readily available substrate for bacteria (Maranger and others 2005) and is likely a major contributor to bacterioplankton production. Allochthonous OM may be important during times of low autochthonous production and high availability of allochthonous OM for pelagic food webs, as for instance during spring flood events (Wikner and others 1999; Figueroa and others 2016). With sufficient autochthonous production, however, allochthonous OM likely plays only a minor role for zooplankton.

Whereas some studies indicated high reliance of benthic consumers on terrestrial matter (Lautenschlager and others 2014; Careddu and others 2015), others showed that marine benthic consumers utilized benthic microalgae despite high 
availability of allochthonous OM (Antonio and others 2010). In our study, variation in allochthony was high among benthic taxonomic groups. The two amphipods showed low utilization of allochthonous OM (1.6\% for Monoporeia and 6.9\% for Corophium) and preferably fed on autochthonous resources. Reliance on allochthonous OM of other benthic taxa varied substantially (10$62 \%)$, indicating that allochthonous OM was at least an alternative resource for some taxa. Interestingly, the predatory isopod Saduria relied to a large extent on allochthonous OM (62\%). This is surprising as a previous study has identified Monoporeia as the major prey item of Saduria (Englund and Leonardsson 2008); however, this study used data for the period between 1983 and 2002. In 2000, Monoporeia densities crashed, whereas at the same time, Marenzellaria densities increased substantially, and Saduria densities declined somewhat in our study area (Figure S3), suggesting that trophic interactions within the benthic food web might have rearranged in recent years. It is beyond our study to speculate about this, and we urge future studies to investigate how changes in species abundance have affected benthic food web dynamics in the Baltic Sea. Regardless, the high allochthony in Saduria highlights that allochthonous OM is transferred to higher trophic levels in benthic food webs.

In our second hypothesis, we assumed that allochthony would decline with increasing distance from the river as the influence of river-transported allochthonous OM decreases. Instead, allochthony was only consistently higher at the station closest to the river mouth (S1) than at the one without significant freshwater input (S4) but only for zoobenthos, not for zooplankton. Average summer primary production in benthic and pelagic habitats has been estimated to 133 and $136 \mathrm{mg} \mathrm{C} \mathrm{m}^{-2}$ day $^{-1}$, respectively, in the Öre estuary (Ask and others 2016). Assuming that river-derived allochthonous OM spreads over the entire Öre estuary, the areal allochthonous carbon loading during summer would equal approximately $1128 \mathrm{mg} \mathrm{C} \mathrm{m}^{-2} \mathrm{day}^{-1}$, which is more than four times higher than the combined (benthic and pelagic) autochthonous production. Much of the riverine allochthonous OM entering the estuary is flocculated close to the river mouth (Forsgren and others 1996; Asmala and others 2014), resulting in higher availability of allochthonous OM close to the river mouth than further out in the estuary. This explains the general high allochthony in zoobenthos with particularly high values closest to the river mouth. Additionally, zoobenthos allochthony was higher at deep than at shallow stations toward the end of the sampling period, in July and August. Although Ask and others (2016) showed that light was generally sufficient for benthic primary production down to $10 \mathrm{~m}$ depth in our study area, they showed a decline with increasing depth, suggesting that allochthonous OM might be more important for zoobenthos when autochthonous sources become limited. In contrast, zooplankton allochthony did not vary spatially. River plumes are very dynamic systems and vary substantially in time and space (Broche and others 1998; Devlin and Schaffelke 2009), and thus, the supply of allochthonous OM along the plume is highly variable (Yamashita and others 2011), especially to the water column. This, combined with a rather small concentration gradient of DOC along the transect and overall low allochthony, likely explains why we did not find any spatial variation in zooplankton allochthony.

Allochthony was, as hypothesized, highest at the beginning of the year. For zoobenthos and zooplankton, allochthony was highest in May. High flood periods typically occur in April and May in the Öre River (Brydsten and Jansson 1989), and our first sampling coincided with the highest peak in water discharge (Figure 1C). The high allochthony of zooplankton might reflect elevated supply of allochthonous versus autochthonous OM and high incorporation of allochthonous OM via bacterioplankton during the high-water discharge period (Wikner and others 1999), whereas high allochthony in zoobenthos already in May suggests high reliance on allochthonous OM over the winter, as turnover rates of ${ }^{2} \mathrm{H}$ are likely higher for zooplankton than zoobenthos. For zooplankton, the contribution of allochthonous OM was negligible during the other sampling months, demonstrating that autochthonous production is much more important for fueling the pelagic food web. In contrast, the contribution of allochthonous OM to zoobenthos was also high in August, highlighting the importance of allochthonous $\mathrm{OM}$ as a resource for zoobenthos in shallow coastal areas. Zoobenthos allochthony was low in June and July, potentially due to either higher availability of benthic primary production through the onset of spring or increased availability of autochthonous detritus settling from the pelagic.

Reliance on allochthonous resources was low for all sticklebacks but high for perch; thus, our hypothesis was only partly confirmed. Perch is an omnivorous predator that generally feeds on zooplankton, macroinvertebrates, and fish. Allochthony in perch was on average $66 \%$, suggesting that perch likely fed to a large extent on zoobenthos. 
Perch has been demonstrated to derive large proportion of its biomass from littoral habitats in lake ecosystems (Bartels and others 2016), and our results highlight the importance of littoral habitats for perch in shallow coastal ecosystems. In contrast, 3spined sticklebacks spend large parts of their life cycle in offshore areas and only migrate to coastal areas to spawn (Borg 1985); thus, we expected low allochthony in this species. However, 9-spined sticklebacks likely spend long time periods close to shore and rely to a larger extent on benthic resources than 3-spined sticklebacks, and it is thus surprising that we found similar contribution of allochthonous OM to both species. One explanation is that 9-spined sticklebacks selectively fed on zoobenthos that rely to a larger extent on autochthonous OM, for instance on Monoporeia. Moreover, feeding habitats might differ from areas where we caught the fish, and 9-spined sticklebacks might consume prey in habitats that were not affected by allochthonous OM.

\section{Sources of Caveat}

As the application of ${ }^{2} \mathrm{H}$ to food web studies has been developed rather recently, the contribution of dietary water to consumer $\mathrm{H}$ still represents a source of high uncertainty (Solomon and others 2009). As Wilkinson and others (2015) demonstrated, $\omega$ ranged between 0.06 and 0.39 and varied between different taxa. In our study, the probability distributions for allochthonous and autochthonous contributions resulting from the mixing model were highly skewed toward the autochthonous end-member for zooplankton and amphipods. For zooplankton, $\omega<0.13$ resulted in precise probability distributions (Figure S4). However, for the two amphipods, only very small $\omega$ $(\omega<0.02$ and $\omega<0.07$ for Monoporeia and Corophium, respectively) resulted in precise solutions. Large values for $\omega$ resulted in skewed probability distributions for almost all consumers (Figure S4). Future studies should continue investigating the contribution of dietary water to consumer $\mathrm{H}$ to improve the application of ${ }^{2} \mathrm{H}$ in food web studies.

We used published estimates of leaf litter as the allochthonous end-member and our own periphyton data as the autochthonous end-member. Although terrestrial vegetation constitutes part of the bulk allochthonous OM, it might not reflect the available allochthonous OM pool for aquatic consumers or the potential range of isotope signatures of allochthonous OM that enters our study system. Thus, we might have over- or underestimated allochthony. Furthermore, the utilization of peri- phyton as an end-member is likely inappropriate for some consumers such as zooplankton and amphipods, as they consume phytoplankton and phytoplankton detritus rather than periphyton. Our estimates of periphyton $\delta^{2} \mathrm{H}$ were within the range of previously calculated signatures of phytoplankton (Wilkinson and others 2015); however, the $\delta^{15} \mathrm{~N}$ likely differs between phytoplankton and periphyton. This might explain why the model did not perform well for groups that rely to a large extent on pelagic resources. Furthermore, the difference in $\delta^{15} \mathrm{~N}$ between the end-members and predators (Saduria and fish) was quite large. Trophic fractionation of ${ }^{15} \mathrm{~N}$ can be highly variable, and some studies suggest a mean fractionation up to $3-3.4 \%$ per trophic level (Post 2002; Vanderklift and Ponsard 2003). However, applying different fractionation factors did not affect allochthony in our study. Another potential source of uncertainty is the $\delta^{15} \mathrm{~N}$ of the end-members, in particular the allochthonous end-member, as $\delta^{15} \mathrm{~N}$ is also highly variable in soils and plant material (Högberg 1997). The absolute values for allochthony should be interpreted with caution. But as the major objective of this study was to compare relative differences in allochthony, we strongly believe that our main conclusions are valid despite of uncertainties in $\omega$ and end-member selection.

\section{Conclusions}

Inputs of allochthonous OM to aquatic ecosystems are predicted to increase in the future. Despite of an increasing understanding of these allochthonous "subsidies" for freshwater systems, we still lack a comparable knowledge for marine ecosystems. Our study illustrates that consumers can track the availability of allochthonous OM as is highlighted by differences in contribution in space and time. However, the extent that allochthonous OM contributed to consumer biomass differed between benthic and pelagic habitats. Overall, zoobenthos relied more on allochthonous OM than zooplankton. This discrepancy is likely explained by the different mechanisms how allochthonous OM enters the food webs. The differences in allochthony suggest that increasing inputs of allochthonous $\mathrm{OM}$, as predicted by climate change scenarios, might affect benthic and pelagic food webs in very different ways. Rising inputs of allochthonous OM have been suggested to limit phytoplankton production in coastal areas and promote bacterial production (Wikner and Andersson 2012), resulting in lower zooplankton and potentially fish biomass (Andersson and others 2015). In contrast, 
zoobenthos will likely be less affected by increasing allochthonous OM concentrations as they can directly utilize allochthonous $\mathrm{OM}$ as an alternative resource. Thus, production in benthic and pelagic habitats might be affected differently with potential consequences for habitat coupling by higher trophic levels.

\section{ACKNOWLEDGEMENTS}

We thank E. Landström, M. Lindvall, Å. Berglund, H. Larsson, and M. Molin for help in the field and in the laboratory, the Umeå Marine Sciences Centre for providing infrastructure, sample analyses, long-term monitoring data for zoobenthos, and perch from the monitoring survey, T. Horstkotte for providing the sampling map, and T. Essington, M.T. Brett, and one anonymous reviewer for their helpful comments on previous versions of the manuscript. This study was funded by a grant from Kempe foundation to $\mathrm{RG}$, a grant from Umeå Marine Sciences Centre to $\mathrm{PB}$, and by the marine strategic research program EcoChange.

\section{OPEN ACCESS}

This article is distributed under the terms of the Creative Commons Attribution 4.0 International License (http://creativecommons.org/licenses/by/ 4.0/), which permits unrestricted use, distribution, and reproduction in any medium, provided you give appropriate credit to the original author(s) and the source, provide a link to the Creative Commons license, and indicate if changes were made.

\section{REFERENCES}

Albright LJ. 1983. Influence of river-ocean plumes upon bacterioplankton production of the Strait of Georgia, British Columbia. Mar Ecol Prog Ser 12:107-13.

Alling V, Humborg C, Mörth C-M, Rahm L, Pollehne F. 2008. Tracing terrestrial organic matter by $\delta^{34} \mathrm{~S}$ and $\delta^{13} \mathrm{C}$ signatures in a subarctic estuary. Limnol Oceanogr 53:2594-602.

Andersson A, Meier HEM, Ripszam M, Rowe O, Wikner J, Haglund P, Eilola K, Legrand C, Figueroa D, Paczkowska J, Lindehoff E, Tysklind M, Elmgren R. 2015. Projected future climate change and the Baltic Sea ecosystem management. Ambio 44:S345-56.

Antonio ES, Kasai A, Ueno M, Won N, Ishihi Y, Yokoyama H, Yamashita Y. 2010. Spatial variation in organic matter utilization by benthic communities from Yura River-Estuary to offshore of Tongo Sea, Japan. Estuar Coast Shelf Sci 86:10717.

Ask J, Karlsson J, Persson L, Ask P, Byström P, Jansson M. 2009. Whole-lake estimates of carbon flux through algae and bacteria in benthic and pelagic habitats of clear-water lakes. Ecology 90:1923-32.
Ask J, Rowe O, Brugel S, Strömgren M, Byström P, Andersson A. 2016. Importance of coastal primary production in the northern Baltic Sea. Ambio 45:635-48.

Asmala E, Bowers DG, Autio R, Kaartokallio H, Thomas DN. 2014. Qualitative changes of riverine dissolved organic matter at low salinities due to flocculation. J Geophys Res Biogeosci 119:1919-33.

Bartels P, Hirsch PE, Svanbäck R, Eklöv P. 2016. Dissolved organic carbon reduces habitat coupling by top predators in lake ecosystems. Ecosystems 19:955-67.

Bianchi TS, Allison AA. 2009. Large-river delta-front estuaries as natural "recorders" of global environmental change. Proc Natl Acad Sci USA 106:8085-92.

Bode A, Varela M, Prego R. 2011. Continental and marine sources of organic matter and nitrogen for rias of northern Galicia (Spain). Mar Ecol Prog Ser 437:13-26.

Borg B. 1985. Field studies on the three-spined sticklebacks in the Baltic. Behaviour 93:153-7.

Broche P, Devenon JL, Forget P, de Maistre JC, Naudin JJ, Cauwet G. 1998. Experimental study of the Rhone plume. Part I: physics and dynamics. Oceanol Acta 21:725-38.

Brydsten L, Jansson M. 1989. Studies of estuarine sediment dynamics using ${ }^{137} \mathrm{Cs}$ from Tjernobyl accident as tracer. Estuar Coast Shelf Sci 28:249-59.

Careddu G, Costantini ML, Calizza E, Carlino P, Bentivoglio F, Orlandi L, Rossi L. 2015. Effects of terrestrial input on macrobenthic food webs of coastal sea are detected by stable isotope analysis in Gaeta Gulf. Estuar Coast Shelf Sci 154:158-68.

Chin-Leo G, Benner R. 1992. Enhanced bacterioplankton production and respiration at intermediate salinities in the Mississippi River plume. Mar Ecol Prog Ser 87:87-103.

Clark JM, Botrell SH, Evans CD, Monteith DT, Bartlett R, Rose R, Newton RJ, Chapman PJ. 2009. The importance of the relationship between scale and process in understanding longterm DOC dynamics. Sci Total Environ 408:2768-75.

Cole JJ, Carpenter SR, Pace ML, Van de Bogert MC, Kitchell JF, Hodgson JR. 2006. Differential support of lake food webs by three types of terrestrial organic carbon. Ecol Lett 9:558-68.

Cole JJ, Prairie YT, Caraco NF, McDowell WH, Tranvik LJ, Striegl RG, Duarte CM, Kortelainen P, Downing JA, Middelburg JJ, Melack J. 2007. Plumbing the global carbon cycle: integrating inland waters into the terrestrial carbon budget. Ecosystems 10:171-84.

Dagg MJ, Benner R, Lohrenz S, Lawrence D. 2004. Transformation of dissolved and particulate materials on continental shelves influenced by large rivers: plume processes. Cont Shelf Res 24:833-58.

Devlin M, Schaffelke B. 2009. Spatial extent of riverine flood plumes and exposure of marine ecosystems in the Tully coastal region, Great Barrier Reef. Mar Freshw Res 60:110922.

Doucett RR, Marks JC, Blinn DW, Caron M, Hungate BA. 2007. Measuring terrestrial subsidies to aquatic food webs using stable isotopes of hydrogen. Ecology 88:1587-92.

Dunton KH, Weingartner T, Carmack EC. 2006. The nearshore western Beaufort Sea ecosystem: circulation and importance of terrestrial carbon in arctic coastal food webs. Prog Oceanogr $71: 362-78$

Englund G, Leonardsson K. 2008. Scaling up the functional response for spatially heterogeneous systems. Ecol Lett 11:4409. 
Figueroa D, Rowe O, Paczkowska J, Legrand C, Andersson A. 2016. Allochthonous carbon: a major driver of bacterioplankton production in the subarctic northern Baltic Sea. Microbiol Aquat Syst 71:789-801.

Fockedey N, Mees J. 1999. Feeding of the hyperbenthic mysid Neomysis integer in the maximum turbidity zone of the Elbe, Westerschelde and Gironde estuaries. J Mar Syst 22:207-28.

Forsgren G, Jansson M, Nilsson P. 1996. Aggregation and sedimentation of iron, phosphorus and organic carbon in experimental mixtures of freshwater and estuarine water. Estuar Coast Shelf Sci 43:259-68.

Freeman C, Evans CD, Monteith DT, Reynolds B, Fenner N. 2001. Export from organic carbon from peat soils. Nature 412:785.

Grasshof K, Ehrhardt M, Kremling K. 1983. Methods of seawater analysis. Weinheim: Verlag Chemie.

Hampton SE, Fradkin SC, Leavitt PR, Rosenberger EE. 2011. Disproportionate importance of nearshore habitat for the food web of a deep oligotrophic lake. Mar Freshw Res 62:350-8.

Hedges JI, Keil RG, Benner R. 1997. What happens to terrestrial organic matter in the ocean? Org Geochem 27:195-212.

Högberg P. 1997. Tansley review no. $95 .{ }^{15} \mathrm{~N}$ natural abundance in soil-plant systems. New Phytol 137:179-203.

Hopkinson CS, Vallino J. 1995. The nature of watershed perturbations and their influence on estuarine metabolism. Estuaries 18:598-621.

Ittekkot V. 1988. Global trends in the nature of organic matter in river suspensions. Nature 332:436-8.

Jansson M, Persson L, De Roos AM, Jones RI, Tranvik LJ. 2007. Terrestrial carbon and intraspecific size-variation shape lake ecosystems. Trends Ecol Evol 22:316-22.

Jonsson M, Stenroth K. 2016. True autochthony and allochthony in aquatic-terrestrial resource fluxes along a landuse gradient. Freshw Sci 35:882-94.

Karlsson J, Berggren M, Ask J, Byström P, Jonsson A, Laudon H, Jansson M. 2012. Terrestrial organic matter support of lake food webs: evidence from lake metabolism and stable hydrogen isotopes of consumers. Limnol Oceanogr 57:1042-8.

Lautenschlager AD, Matthews TG, Quinn GP. 2014. Utilization of organic matter by invertebrates along an estuarine gradient in an intermittently open estuary. Estuar Coast Shelf Sci $149: 232-43$.

Maranger RJ, Pace ML, del Giorgio PA, Caraco NF, Cole JJ. 2005. Longitudinal spatial patterns of bacterial production and respiration in a large river-estuary: Implications for ecosystem carbon consumption. Ecosystems 8:318-30.

McCallister SL, Bauer JE, Cherrier JE, Ducklow HW. 2004. Assessing sources and ages of organic matter supporting river and estuarine bacterial production: A multiple-isotope $\left(\Delta^{14} \mathrm{C}\right.$, $\delta^{13} \mathrm{C}$, and $\delta^{15} \mathrm{~N}$ ) approach. Limnol Oceanogr 49:1687-702.

McCutchan JH, Lewis WM, Kendall C, McGrath CC. 2003. Variation in trophic shift for stable isotope ratios of carbon, nitrogen, and sulfur. Oikos 102:378-90.

Meybeck M. 1982. Carbon, nitrogen, and phosphorus transport by world rivers. Am J Sci 282:401-50.

Minor EC, Simjouw JP, Mulholland MR. 2006. Seasonal variations in dissolved organic carbon concentrations and characteristics in a shallow coastal bay. Mar Chem 101:166-79.

Monteith DT, Stoddard JL, Evans CD, de Wit HA, Forsius M, Hogasen T, Wilander A, Skjelvale BL, Jeffries DS, Vuorenmaa J, Keller B, Kopacek J, Vesely J. 2007. Dissolved organic carbon trends resulting from changes in the atmospheric deposition chemistry. Nature 450:537-U9.

Montero P, Daneri G, González HE, Iriarte JL, Tapia FJ, Lizárraga L, Sanchez N, Pizarro O. 2011. Seasonal variability of primary production in a fjord ecosystem of the Chilean Patagonia: Implications for the transfer of carbon within pelagic food webs. Cont Shelf Res 31:202-15.

Olenin S, Leppäkoski E. 1999. Non-native animals in the Baltic Sea: alteration of the benthic habitats in coastal inlets and lagoons. Hydrobiologia 393:233-43.

Opsahl S, Benner R. 1997. Distribution and cycling of terrigenous dissolved organic matter in the ocean. Nature 386:480-2.

Parnell A, Jackson A (2013) Siar: stable isotope analysis in R. R package version 4.2.

Peterson BJ, Howarth RW, Garritt RH. 1985. Multiple stable isotopes used to trace the flow of organic matter in estuarine food webs. Science 227:1361-3.

Post DM. 2002. Using stable isotopes to estimate trophic position: models, methods, and assumptions. Ecology 83:703-18.

Premke K, Karlsson J, Steger K, Gudasz C, von Wachenfeldt E, Tranvik LJ. 2010. Stable isotope analysis of benthic fauna and their food sources in boreal lakes. J N Am Benthol Soc 29:1339-48.

R Core Team. 2016. R: a language and environment for statistical computing. Vienna: R Foundation for Statistical Computing.

Schindler DE, Scheuerell MD. 2002. Habitat coupling in lake ecosystems. Oikos 98:177-89.

Sholkovitz ER. 1976. Flocculation of dissolved organic and inorganic matter during mixing of river water and seawater. Geochim Cosmochim Acta 40:831-5.

Solomon CT, Cole JJ, Doucett RR, Pace ML, Preston ND, Smith LE, Weidel BC. 2009. The influence of environmental water on the hydrogen stable isotope ratio in aquatic consumers. Oecologia 161:313-24.

Szczepanska A, Zaborska A, Maciejewska A, Kulinski K, Pempkowiak J. 2012. Distribution and origin of organic matter in the Baltic Sea sediments dated with ${ }^{210} \mathrm{~Pb}$ and ${ }^{137} \mathrm{Cs}$. Geochronometria 39:1-9.

Tranvik LJ, Downing JA, Cotner JB, Loiselle SA, Striegl RG, Ballatore TJ, Dillon P, Finlay K, Fortino K, Knoll LB, Kortelainen PL, Kutser T, Larsen S, Laurion I, Leech DM, McCallister SL, McKnight DM, Melack JM, Overholt E, Porter JA, Prairie Y, Renwick WH, Roland F, Sherman BS, Schindler DW, Sobek S, Tremblay A, Vanni MJ, Verschoor AM, von Wachenfeldt E, Weyhenmeyer G. 2009. Lakes and reservoirs as regulators of carbon cycling and climate. Limnol Oceanogr 54:2298-314.

Tranvik LJ, Jansson M. 2002. Climate change and terrestrial export of organic carbon. Nature 415:861-2.

Vanderklift MA, Ponsard S. 2003. Sources of variation in consumer-diet $\delta^{15} \mathrm{~N}$ enrichment: a meta-analysis. Oecologia 136:169-82.

Vander Zanden MJ, Vadeboncoeur Y. 2002. Fish as integrators of benthic and pelagic food webs in lakes. Ecology 83:2152-61.

Wikner J, Andersson A. 2012. Increased freshwater discharge shifts the carbon balance in the coastal zone. Global Change Biol 18:2509-19.

Wikner J, Cuadros R, Jansson M. 1999. Differences in consumption of allochthonous DOC under limnic and estuarine conditions in a watershed. Aquat Microb Ecol 17:289-99.

Wilkinson GM, Cole JJ, Pace ML. 2015. Deuterium as a food source tracer: sensitivity to environmental water, lipid con- 